\title{
12. HEAVY MINERAL CHARACTERISTICS AND DISPERSAL PATTERNS FROM DSDP LEG 35, SOUTHEAST PACIFIC BASIN
}

\author{
Christopher S. Peters, St. Lawrence University, Canton, New York \\ and \\ Charles D. Hollister, Woods Hole Oceanographic Institution, Woods Hole, Massachusetts
}

\begin{abstract}
Modal analysis of heavy mineral suites from the four sites of Leg 35 has revealed pyroxenes and amphiboles to be the dominant species. The mineralogies of sediments from the sites reflect their source rock type, Sites 322 and 325 having a common source of Upper Cretaceous intrusives from the Antarctic Peninsula, and Sites 323 and 324 deriving their terrigenous material from older metamorphics and intrusives from the area of the Eights Coast, and younger volcanics from the Jones Mountains, or Peter I Island.

Relative degree of etching on clinopyroxene grains reflects the extent to which intrastratal solution has occurred. At Site 325, a sudden change in mineralogy, from a dominantly pyroxene assemblage to a pyroxene-amphibole assemblage above it correlates with an abrupt increase in intensity of etching as well as an increase in ice-rafting. A change in source rock type, related to the advent of a late Miocene or early Pliocene glaciation and attendant ice-rafting activity, is suggested as the cause. Glaciation may have eroded younger, less basic intrusives, and transported them from the continent, resulting in a changed mineral assemblage; alternatively, the increase in erosion rates caused by glaciation may have contributed to higher rates of accumulation and thus to a greater degree of intrastratal solution in sediments of high water content.
\end{abstract}

\section{INTRODUCTION}

Minor amounts of coarse-grained terrigenous material were recovered from cores of all four sites of Leg 35, in the Southeast Pacific Basin off the coast of West Antarctica (Figure 1). Evidence from bottom photos (Hollister and Heezen, 1967); piston cores (Kennett and Brunner, 1973); and seismic reflection profiles (Tucholke and Houtz, this volume) indicates that the primary modes of transport and deposition of these sediments are turbidity currents, contour currents, and ice-rafting. Because of their continental origin, the study of this material provides clues to the source area rock types, thus indicating possible dispersal routes.

A heavy mineral analysis of such deposits is particularly valuable in this respect, and not only provides clues as to provenance, but also to possible diagenetic alterations of the sediments. We engaged in this study primarily to correlate the heavy mineralogy of the sediment cores with the probable source area or areas and to study those physical properties of the mineral grains that might give clues to the presence and nature of diagenetic changes.

\section{METHODS OF ANALYSIS}

Core samples were disaggregated with a solution of $\mathrm{Na}_{2} \mathrm{PO}_{4}$, and when necessary, by use of a mortar and pestle. Material finer than $44 \mu \mathrm{m}$ was removed by wet sieving, and after drying, a standard heavy mineral separation was performed on the samples using tetrabromoethane (sp. gr. 2.9). Both the light and heavy minerals were mounted on slides using Caedax (R.I. = 1.55). A modal line-count analysis of each heavy mineral slide was taken, terminating when the count reached 100 nonopaque heavy minerals for one slide. In a few cases, when the total number on the slide was less than 100 , only 50 nonopaques were tabulated. Slides with fewer than 50 nonopaques were not used except in special cases. Results are presented in Table 1.

Separations were generally successful, but we frequently found an occasional quartz or feldspar grain, or fragments of biogenic material on the heavy mineral slide. Lithified clay lumps that were not disaggregated were present on a few slides. Such irregularities were ignored in grain counts. Particularly interesting was the occurrence of phosphatic fish fragments including teeth (Figure 2) of the type described by McKnight (1974) which in local occurrences were the dominant constituent. Other peculiarities included etchings of mineral grains, especially clino- and orthopyroxenes. The importance of these is discussed below.

It was necessary to use reflected light for Sample 323$4, \mathrm{CC}$ because of the large size of the grains present; however, there were less than 50 nonopaque grains, and thus this sample was not included in Table 1. All other slides were identified under transmitted light using a polarizing microscope.

\section{SITE SUMMARIES}

Because the heavy mineral assemblages were dominated by pyroxenes and amphiboles, and to a lesser extent epidotes and garnets, we focused on these three 
IRREGULAR HILLS AND HYPERBOLA

跣累 FLAT, REFLECTIVE, LAMINATED

$\square$ SLOPING, MOD. LAMINATED

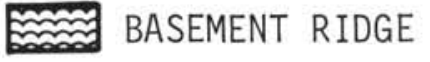

ZZ FINELY LAMINATED
啳䎴 HIGHLY REFLECTIVE, INTERM. LAMINATED

DIJ STEEP REFLECTIVE SLOPE

Gid FLAT REFLECTIVE SHELF

$\rightarrow \rightarrow .$.
$\rightarrow-$ BURIED CANYON
$\longrightarrow$ INACTIVE CANYON
$\rightarrow$ ACTIVE CANYON

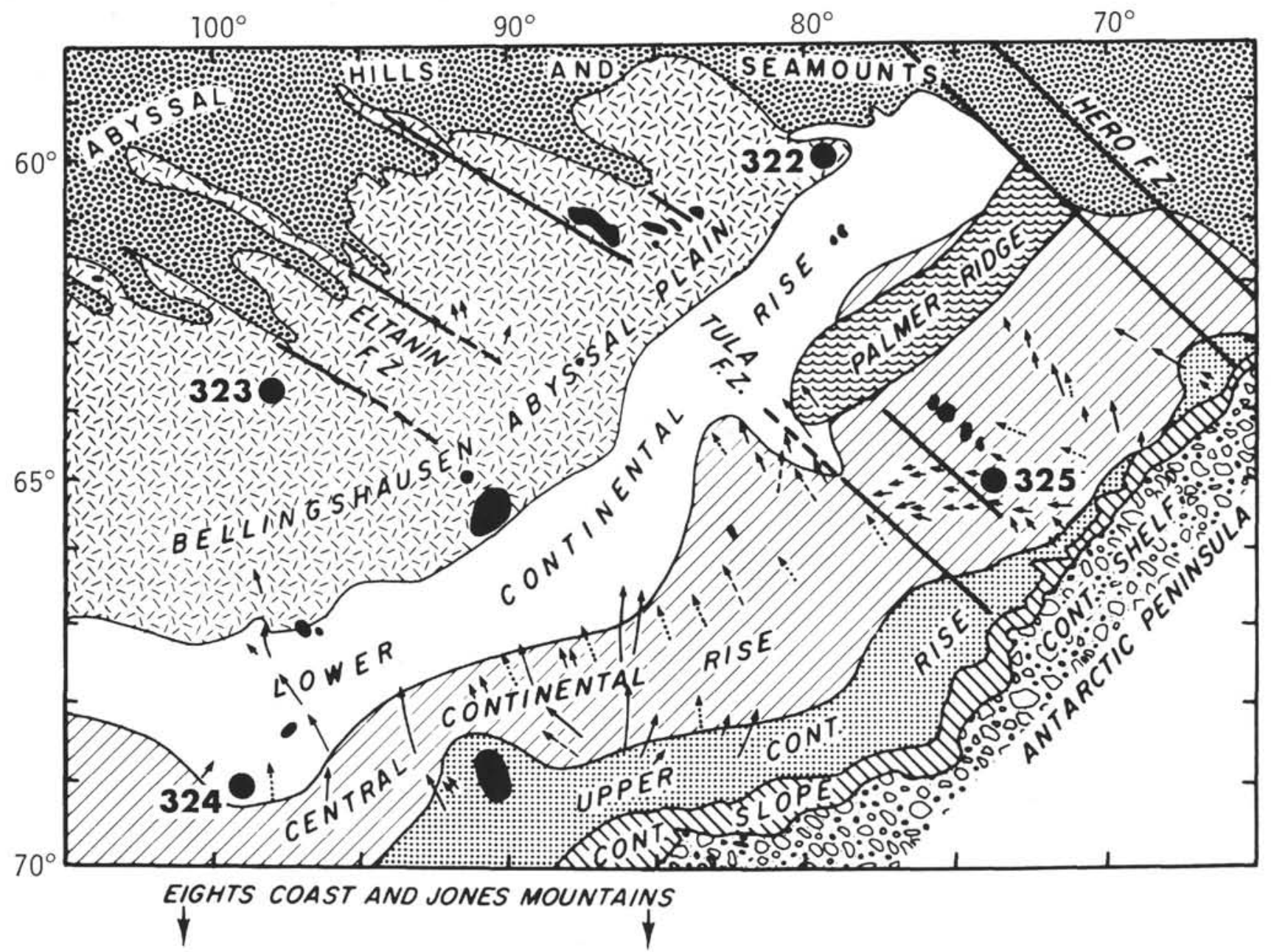

Figure 1. Location map of the four sites of DSDP Leg 35 (from Tucholke and Houtz, this volume).

mineral groups which generally comprised more than $60 \%$ and up to $99 \%$ of the nonopaque heavy minerals.

\section{Site 322}

Pyroxenes dominate sediments from Site 322 (Figure 3 ); there are less amounts of amphiboles, and a few garnets and epidotes. Rare occurrences of apatite, sphene, and zircon were found; apatite occurred as small, clear, prismatic grains, and zircon occurred generally as near-perfect euhedral crystals with slightly rounded ends (Figure 4). Phosphatic fish fragments, including well-preserved teeth (Figure 2), are the dominant constituent of Samples 5, CC and 8, CC. Although their occurrence is noted in Table 1, they are not represented in Figure 3.

Pyroxenes dominate the entire sedimentary sequence in quantities up to $75 \%$ of the nonopaque grains, the clinopyroxenes being somewhat more ubiquitous than orthopyroxenes. Clinopyroxenes range in appearance from a rounded, unetched variety to a strongly etched type displaying a pale green nonpleochroic hue. A triangular diagram of the relative degree of etching of these grains reveals a correlation between etching and depth in the hole (Figure 5). The effect of intrastratal solution on heavy mineral assemblages has been considered a key indicator of diagenetic processes (Pet- 


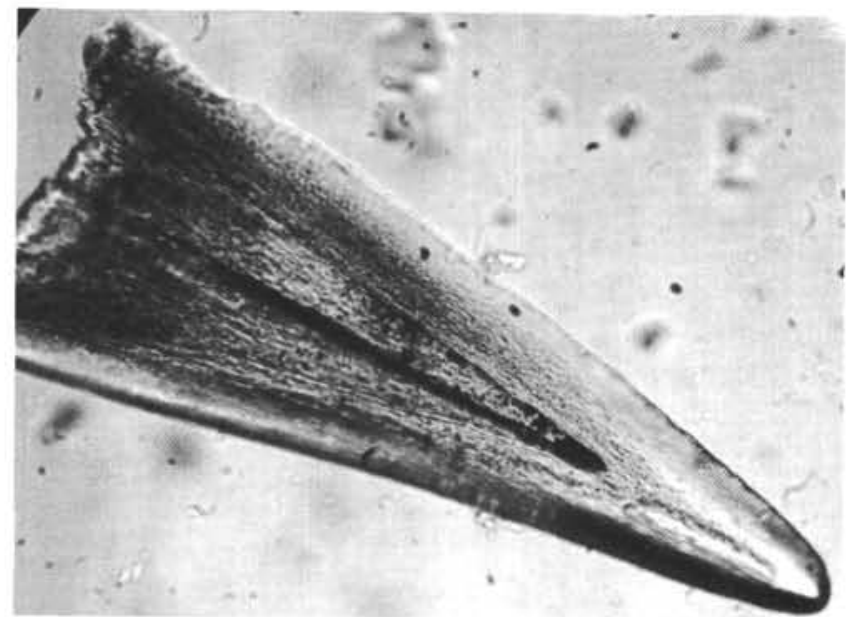

Figure 2. Fish fragment, possibly a tooth, Sample 323-8, CC. (See Figure 8 for scale.)

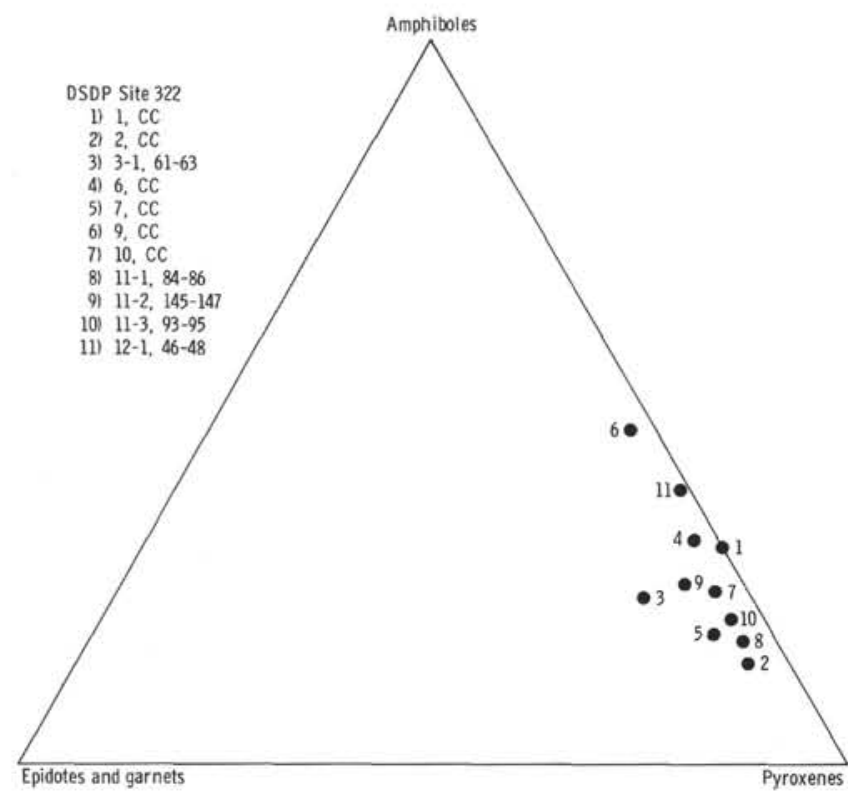

Figure 3. Triangular diagram of heavy mineral suites of Site 322.

tijohn, 1941, 1949; van Andel, 1959; Blatt and Sutherland, 1969).

Fifty augite grains were counted on each available slide and each grain was designated as unetched to slightly etched, slightly to moderately etched, or strongly etched. Because there is no standard quantitative index, the assignment of a grain to a particular category is subjective (Scheidegger et al., 1973), but an attempt was made to be as unbiased as possible. Results indicate a general trend of a greater degree of etching downhole.

The orthopyroxenes, enstatite and hypersthene, and the amphibole hornblende are also common. Orthopyroxene grains ranged in appearance from flat and flaky to highly pitted (Figure 6) to strongly etched (Figure 7). Hornblende occurred in rectangular, strongly pleochroic green grains with good cleavage and was common to all sites (Figure 8). It occasionally has the appearance, as did some grains at Site 325 , of pyroxene with the characteristic schiller structure (Figure 9), and

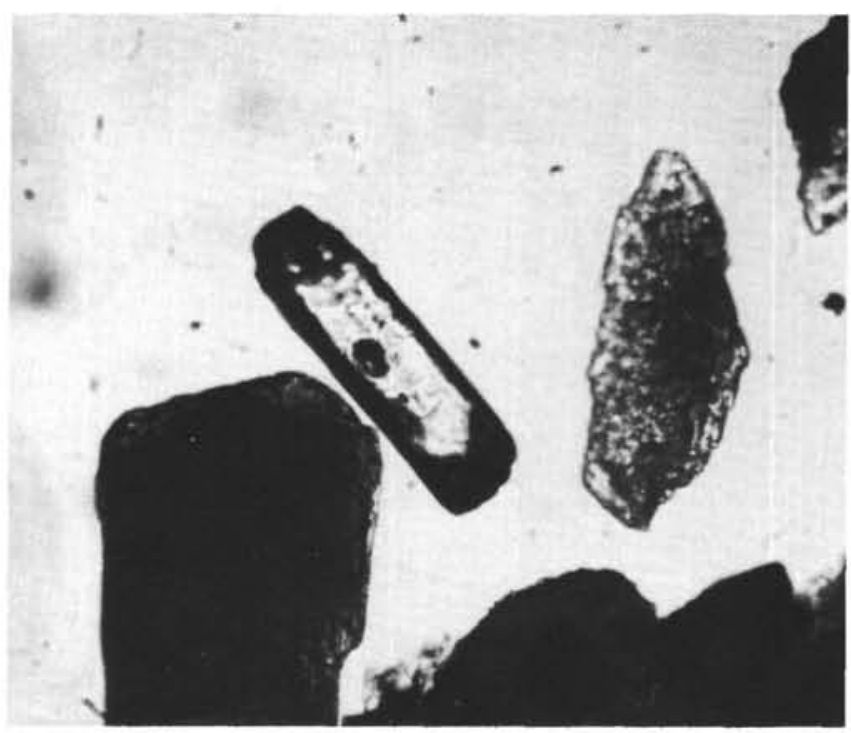

Figure 4. Typical zircon grain, euhedral crystal with rounded ends; grain to the left of it is a moderately etched orthopyroxene; Sample 325-3-1, 115-116 cm. (See Figure 8 for scale.)

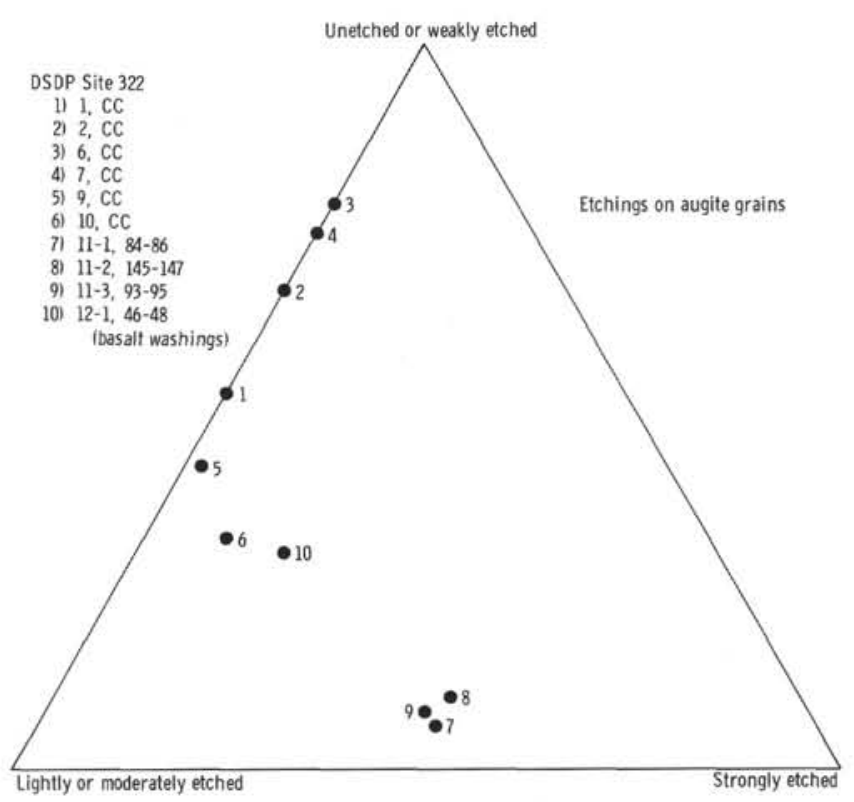

Figure 5. Triangular diagram showing relative degree of etching on clinopyroxene grains at Site 322.

could only be distinguished by its strong pleochroism. Such grains might represent pyroxene that has been replaced by hornblende, the significance of which is discussed below. Brown hornblende was also present in minor quantities.

\section{Site 323}

Amphiboles and lesser amounts of pyroxenes also dominated the assemblages at Site 323 . Although we did not examine a sufficient number of slides for a truly representative sample of this site, the amphibole and pyroxene percentages seem to vary widely (Figure 10). Accessories such as rutile and sphene occur in slightly 


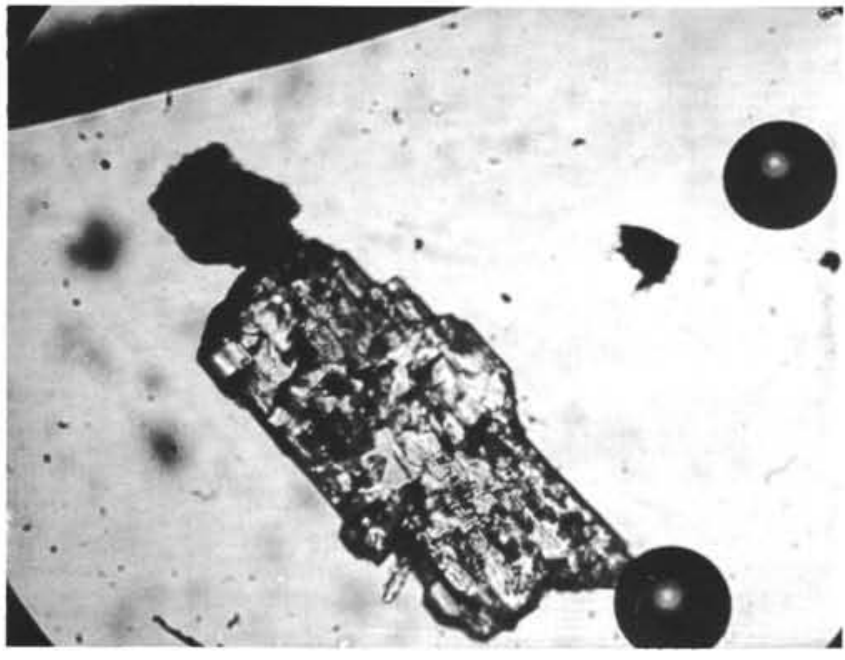

Figure 6. Pitted surface texture of orthopyroxene, Sample 322-3-1, 61-63 cm. (See Figure 8 for scale.)

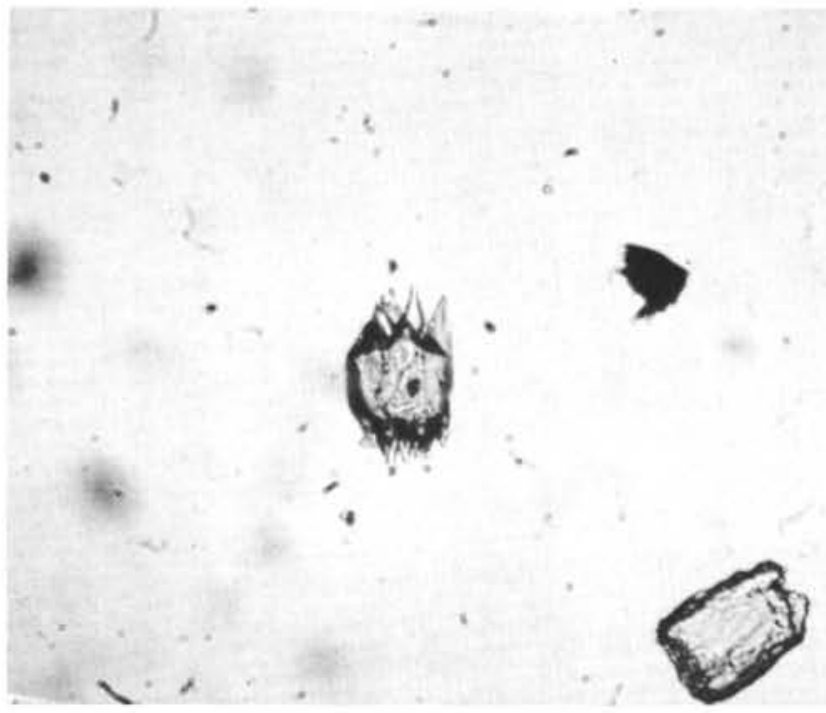

Figure 7. Orthopyroxenes, etched and slightly etched varieties, Sample 322-12-1, 46-48 cm. (See Figure 8 for scale.

greater quantities than at Site 322 as do the micas. Micas occur as green or brownish flakes, and because of their nature are viewed normal to their 001 cleavage face.

Augite grains show well-developed etching (Figure 11 ), but because they occur less frequently than at Site 322 , it is not possible to present a triangular diagram of their relative degree of etching that would truly be representative.

Particularly interesting in this hole is Sample 4, CC which, because of its large grain size, was viewed in reflected light. The size of the grains suggests ice-rafting, which in view of their age (middle Miocene), further supports the observation that Antarctica underwent severe glaciation at this time (Jacobs, 1974; Ciesielski and Weaver, 1974; Kennett and Brunner, 1973). The great majority of the nonopaque grains on this slide are

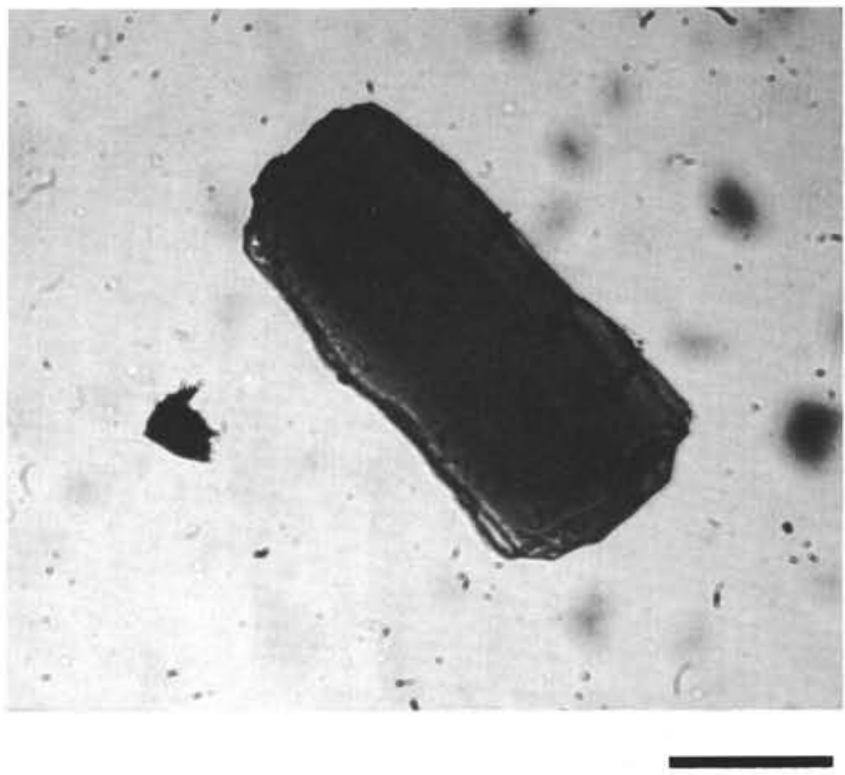

Figure 8. Typical hornblende grain, Sample 325-1-1, 45-46 $\mathrm{cm}$.

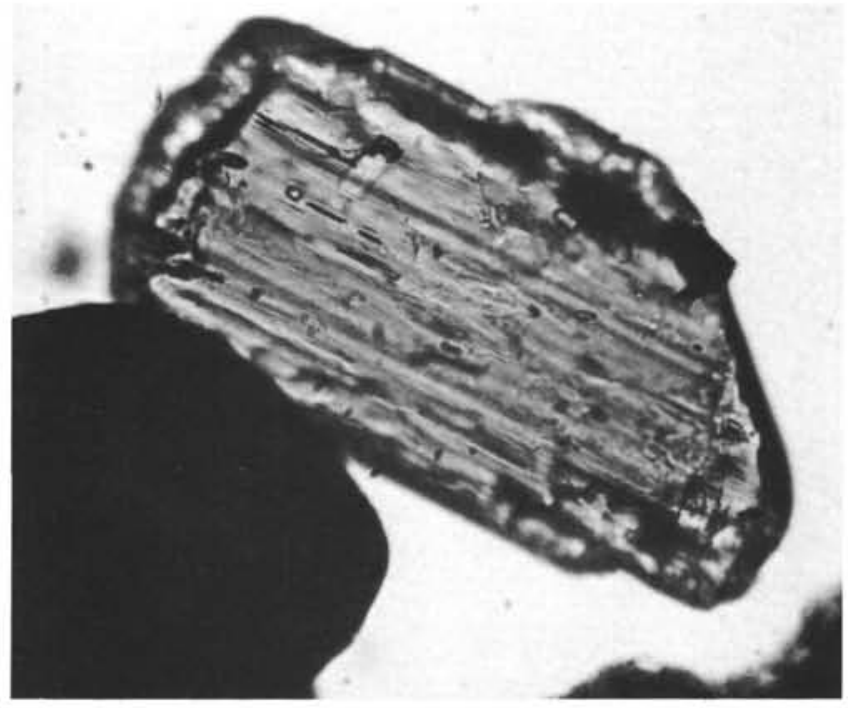

Figure 9. Hornblende, showing pyroxene schillerization, suggesting replacement of pyroxene by hornblende, Sample 325-3-1, 115-116 cm. (See Figure 8 for scale.)

pyroxenes, but there were insufficient grains to be listed in Table 1 .

\section{Site 324}

Site 324 shows a marked similarity to Site 323 . Amphiboles are the dominant mineral type (Figure 12) with epidote and garnet and other accessories (especially rutile and zircon).

The two lower samples in Core 5 are apparent anomalies, the bulk of their constituents being a ferrous variety of diopside with numerous inclusions.

Orthopyroxenes range from unetched (Figure 13) to strongly etched (Figure 14). Enstatite is of the unetched 


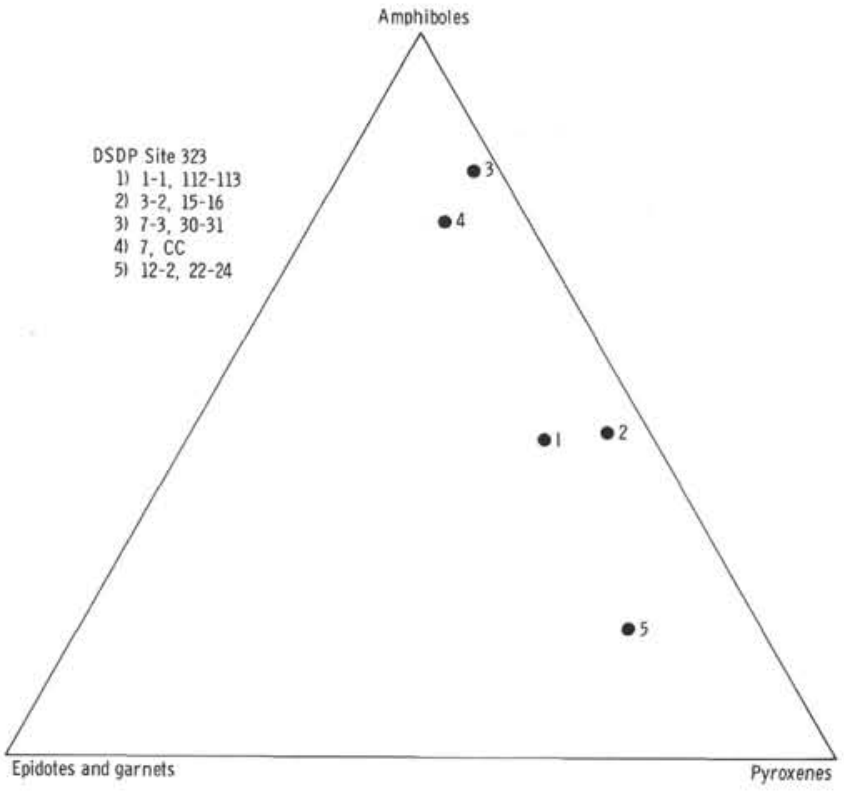

Figure 10. Triangular diagram of heavy mineral suites of Site 323.

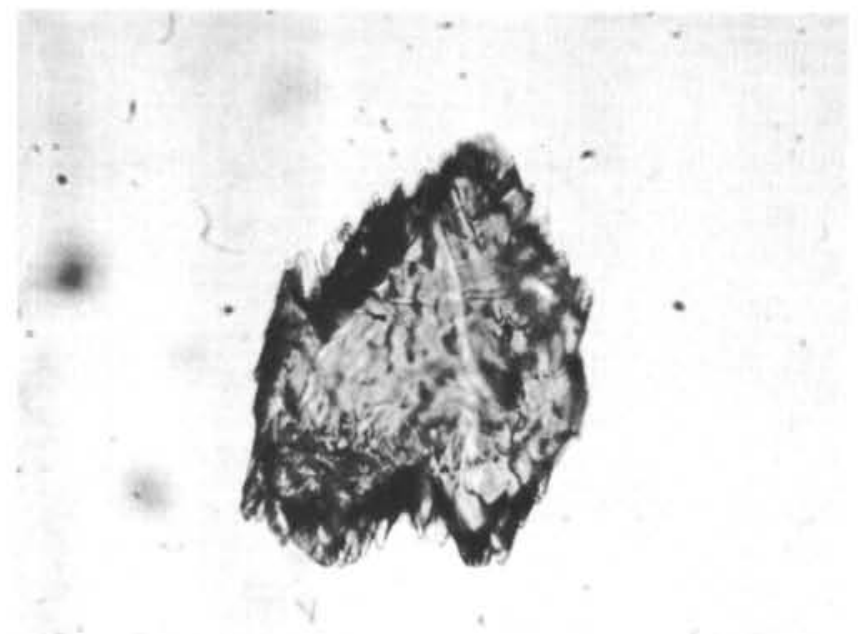

Figure 11. Strongly etched augite grain, Sample 323-3-2, $15-16 \mathrm{~cm}$. (See Figure 8 for scale.)

variety, and the more ferrous, slightly pleochroic hypersthene displays well-developed etchings and schillerization. Some clinopyroxenes also show evidence of etching, but as at Site 323 the abundance of clinopyroxenes relative to Site 322 was not sufficient to include on a triangular diagram.

Epidote is a common mineral at this site and typically occurs as bright yellow, prismatic crystals with jagged edges and a broken surface texture (Figure 15). Garnets are also more common here than at Site 322 and display good conchoidal fracture, with a clear to pale pinkishred color (Figure 16).

\section{Site 325}

This site is particularly interesting in that there is a distinct change in mineralogy downhole (Figure 17). An assemblage of amphibole and pyroxene in near-equal
TABLE 1A

Frequencies of Heavy Mineral Grains

\begin{tabular}{|c|c|c|c|c|c|c|c|c|c|c|c|}
\hline $\begin{array}{c}\text { Sample } \\
\text { (Interval in } \mathrm{cm} \text { ) }\end{array}$ & 을 & 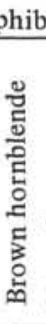 & 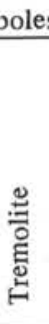 & 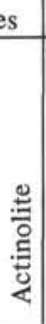 & 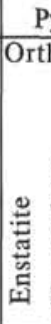 & 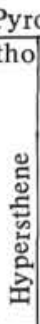 & 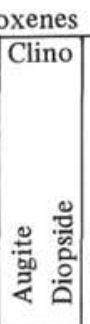 & 总 & 怤 & & 总 \\
\hline $322-1, \mathrm{CC}$ & 28 & & & & 20 & & 46 & & & & 2 \\
\hline $322-2, \mathrm{CC}$ & 11 & & & & 26 & 2 & 38 & 4 & & & \\
\hline $322-3-1,61-63$ & 19 & & & & & 3 & $\begin{array}{ll}45 & 3\end{array}$ & 11 & & & \\
\hline $322-5, \mathrm{CC}$ & 1 & & & & & & $\begin{array}{ll}7 & 13\end{array}$ & & & & \\
\hline $322-6, \mathrm{CC}$ & 24 & 2 & & & 20 & 5 & 30 & 2 & & & 4 \\
\hline $322-7, \mathrm{CC}$ & 13 & 2 & & & 21 & 3 & 40 & 4 & 2 & & 6 \\
\hline $322-8, \mathrm{CC}$ & & & 4 & 1 & & 5 & 4 & 2 & 1 & & 6 \\
\hline 322 & 34 & 4 & 2 & & 16 & & 28 & 1 & 1 & 4 & 1 \\
\hline 322 & 19 & 1 & 2 & & 22 & 9 & 35 & 2 & 2 & 1 & \\
\hline $322-11-1,84$ & 13 & & 3 & & 23 & 9 & 43 & 3 & 1 & & \\
\hline $322-11-2$ & 20 & & 2 & & 15 & 8 & $\begin{array}{ll}37 & 1\end{array}$ & 5 & 1 & & 1 \\
\hline $322-11-3$, & 16 & & & 1 & 16 & 5 & $\begin{array}{ll}43 & 3\end{array}$ & & & & 1 \\
\hline $322-12-1,4$ & 38 & & & & 21 & 2 & 37 & & 1 & & \\
\hline $323-1-1,1$ & 39 & & 2 & & 8 & & $\begin{array}{ll}15 & 17\end{array}$ & 9 & 3 & 3 & \\
\hline $323-3$ & 34 & & & 3 & & & $\begin{array}{lll}28 & 13\end{array}$ & 4 & & 7 & \\
\hline $323-7-3,30$ & 51 & & & 4 & & 1 & 8 & 1 & 1 & 7 & 5 \\
\hline $323-7, \mathrm{CC}$ & 53 & 4 & 2 & 1 & 10 & & 3 & 2 & 6 & & 4 \\
\hline $323-$ & 11 & & 2 & & 36 & 1 & 11 & & 10 & 15 & \\
\hline 324-1 & 21 & & 2 & 1 & 5 & & 42 & 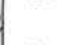 & 1 & 2 & 1 \\
\hline $324-1$ & 50 & & 1 & 1 & 9 & & 13 & 1 & 3 & 1 & 1 \\
\hline $324-$ & 35 & 1 & 3 & 4 & & 1 & 143 & 5 & 3 & 16 & \\
\hline $324-$ & 29 & & & & & 4 & $\begin{array}{ll}7 & 3\end{array}$ & 10 & 9 & & 7 \\
\hline $324-5$ & 30 & 1 & 2 & & 2 & & 126 & 2 & & 23 & \\
\hline $324-5-3,38$ & 12 & & & 1 & & 2 & 340 & 4 & & & 4 \\
\hline $324-5$, CC & 15 & & 1 & & & 2 & 732 & 6 & & 12 & \\
\hline $324-9-1$, & 43 & 4 & 2 & & & 1 & $\begin{array}{ll}4 & 4\end{array}$ & & 10 & 6 & 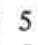 \\
\hline $325-1-1$, & 38 & & & 1 & 11 & 5 & $\begin{array}{ll}20 & 4\end{array}$ & 1 & & 1 & . \\
\hline-45 & 31 & 2 & 2 & 1 & 14 & 4 & 118 & 6 & & 2 & t \\
\hline 325 & 35 & & 1 & & 16 & 8 & 17 & & & 4 & . \\
\hline 325 & 23 & & & 2 & 12 & 6 & 14 & 4 & & 3 & 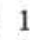 \\
\hline $325-$ & 28 & & 3 & & 13 & 6 & 22 & & & 3 & 3 \\
\hline $325-3$ & 27 & 3 & 2 & 5 & 7 & 8 & 231 & 11 & 1 & 3 & \\
\hline $325-3, \mathrm{CC}$ & 38 & & 2 & & 13 & 7 & 22 & 2 & 1 & & 5 \\
\hline $325-4$ & 13 & & 2 & 1 & 14 & 2 & $27 \quad 16$ & 11 & 1 & & 3 \\
\hline $325-5-2,12$ & 7 & & 1 & 2 & & 4 & 426 & 7 & & 19 & 1 \\
\hline $325-6, \mathrm{CC}$ & 22 & & & & 19 & 2 & 48 & 1 & & & 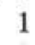 \\
\hline $325-7, \mathrm{CC}$ & 8 & & 3 & 1 & 7 & 1 & 422 & 18 & 7 & 1 & 2 \\
\hline $325-8, \mathrm{CC}$ & 4 & 2 & & & 15 & 2 & 68 & & 1 & & 4 \\
\hline $325-8-1,11$ & 9 & 3 & 1 & 1 & 8 & 1 & 66 & 1 & 8 & 1 & \\
\hline $325-9-1,122-123$ & & 6 & & 2 & 9 & 9 & 35 & 7 & 3 & 7 & 3 \\
\hline $325-9-3,5-7$ & 8 & 1 & 1 & & 13 & 4 & $\begin{array}{ll}36 & 2\end{array}$ & 5 & & 4 & . \\
\hline $325-10-1,75-77$ & 9 & 1 & 2 & 5 & & 4 & $\begin{array}{ll}39 & 3\end{array}$ & 14 & 1 & 1 & \\
\hline
\end{tabular}

quantities gives way to a dominantly pyroxene assemblage below approximately 200 meters subbottom. Both amphiboles and pyroxenes have a wide range of appearance. Amphiboles range from the average prismatic grain with well-developed cleavage (Figure 8) to those displaying slight schillerization (Figure 9) as was discussed above (Site 322), which may indicate replacement of pyroxene by hornblende. An excellent specimen of the schiller structure in hypersthene is shown in Figure 18, and a strongly etched variety is shown in Figure 19. Augite grains range from unetched 
TABLE 1B

Frequencies of Heavy Mineral Grains

\begin{tabular}{|c|c|c|c|c|c|c|c|c|}
\hline $\begin{array}{c}\text { Sample } \\
\text { (Interval in } \mathrm{cm} \text { ) }\end{array}$ & 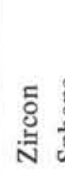 & 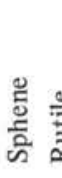 & 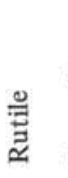 & 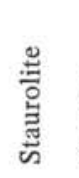 & 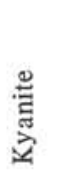 & 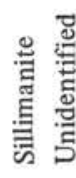 & 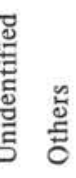 & 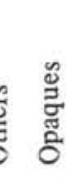 \\
\hline $322-1, \mathrm{CC}$ & 1 & & & & & & 3 & 51 \\
\hline $322-2, \mathrm{CC}$ & & & & 1(?) & & & 16 & 43 \\
\hline $322-3-1,61-63$ & 7 & 8 & & & & 2 & & 55 \\
\hline $322-5, \mathrm{CC}$ & & & & & & & $79^{2}$ & $9^{\text {a }} 51$ \\
\hline $322-6, \mathrm{CC}$ & 2 & & & & & & 1 & 34 \\
\hline $322-7, \mathrm{CC}$ & 2 & & 1 & & & & 4 & 37 \\
\hline $322-8, \mathrm{CC}$ & 2 & 11 & 1 & & & & 25 & $5^{\mathrm{a}} 53$ \\
\hline $322-9, \mathrm{CC}$ & & & & & & & 7 & 50 \\
\hline $322-10, \mathrm{CC}$ & 2 & & 1 & & & & 4 & 17 \\
\hline $322-11-1,84-86$ & & & & & & & 6 & 25 \\
\hline $322-11-2,145-147$ & & & & & & & 11 & 173 \\
\hline $322-11-3,93-95$ & 2 & 11 & 1 & & & & 8 & 36 \\
\hline $322-12-1,46-48$ & 1 & & & & & & & 17 \\
\hline $323-1-1,112-113$ & & 32 & 2 & & & & & $4^{b} 72$ \\
\hline $323-3-2,15-16$ & 1 & 16 & $\begin{array}{ll}6 & 1\end{array}$ & 1 & $3(?)$ & & & \\
\hline $323-7-3,30-31$ & & 21 & 12 & $2(?)$ & & & 13 & 6 \\
\hline $323-7, \mathrm{CC}$ & 10 & 22 & 2 & & & & 4 & 18 \\
\hline $323-12-2,22-24$ & 2 & 2 & & $1(?)$ & & & 5 & 29 \\
\hline $324-1-3,142-143$ & & 3 & & 1 & & & 6 & $1^{c} 197$ \\
\hline $324-1, \mathrm{CC}$ & 12 & 12 & 21 & 1 & & & 4 & 87 \\
\hline $324-2-3,25-30$ & & & 8 & 3 & 3 & 1 & 4 & 11 \\
\hline $324-2, \mathrm{CC}$ & 12 & & 33 & 3 & & & 5 & 60 \\
\hline $324-5-2,100-101$ & & 22 & 21 & $1(?)$ & & 114 & 4 & 25 \\
\hline $324-5-3,38-40$ & & 33 & 34 & $4(?)$ & & & 7 & $2^{\mathrm{d}} 18$ \\
\hline $324-5, \mathrm{CC}$ & & 11 & 11 & 1(?) & & 14 & 4 & 18 \\
\hline $324-9-1,90-92$ & 1 & & 41 & 1(?) 1 & 1 & 18 & 8 & 40 \\
\hline $325-1-1,0-20$ & 1 & & & & & 13 & 3 & 45 \\
\hline $325-1-1,45-46$ & & & 12 & 2 & 3 & 210 & 0 & 33 \\
\hline $325-1, \mathrm{CC}$ & & & & & & 14 & 4 & $2^{\mathrm{e}} 13$ \\
\hline $325-2-2,122-123$ & 1 & 21 & 14 & 4 & & 28 & 8 & 25 \\
\hline $325-2, \mathrm{CC}$ & 1 & & & & & 20 & 20 & 11 \\
\hline $325-3-1,115-116$ & 1 & & & 3 & & & 5 & 16 \\
\hline $325-3, \mathrm{CC}$ & 2 & & & 2 & & & 7 & 56 \\
\hline $325-4-2,27-30$ & 1 & & & & 2 & & 5 & $2^{\mathrm{f}} 12$ \\
\hline $325-5-2,120-122$ & 1 & & 1 & 2 & 2 & 24 & $4 \quad 1$ & $1^{\mathrm{f}} 116$ \\
\hline $325-6, \mathrm{CC}$ & & 1 & & & & & 6 & 55 \\
\hline $325-7, \mathrm{CC}$ & & & 1 & & & & 7 & 27 \\
\hline $325-8, \mathrm{CC}$ & & & & & & & 4 & 31 \\
\hline $325-8-1,118-120$ & & & 1 & 1 & 1 & & & 257 \\
\hline $325-9-1,122-123$ & & & 1 & 2 & 2 & 16 & 6 & 86 \\
\hline $325-9-3,5-7$ & & & 2 & 3 & 3 & 19 & 9 & 32 \\
\hline $325-10-1,75-77$ & & & 1 & 1 & & 28 & 839 & $9 \quad 18$ \\
\hline
\end{tabular}

${ }^{\text {a}}$ Fish fragments.

${ }^{\mathrm{b}}$ Wollastonite(?) and spinel(?).

${ }^{\mathrm{c}}$ Spinel(?).

dMonazite(?).

${ }^{\mathrm{e}}$ Zeolites.

${ }^{f}$ Glaucophone.

$\mathrm{g}_{\text {Andalusite(?). }}$

(Figure 20) to weakly etched (Figure 21) to moderately etched (Figure 22) to strongly etched (e.g., Figure 11).

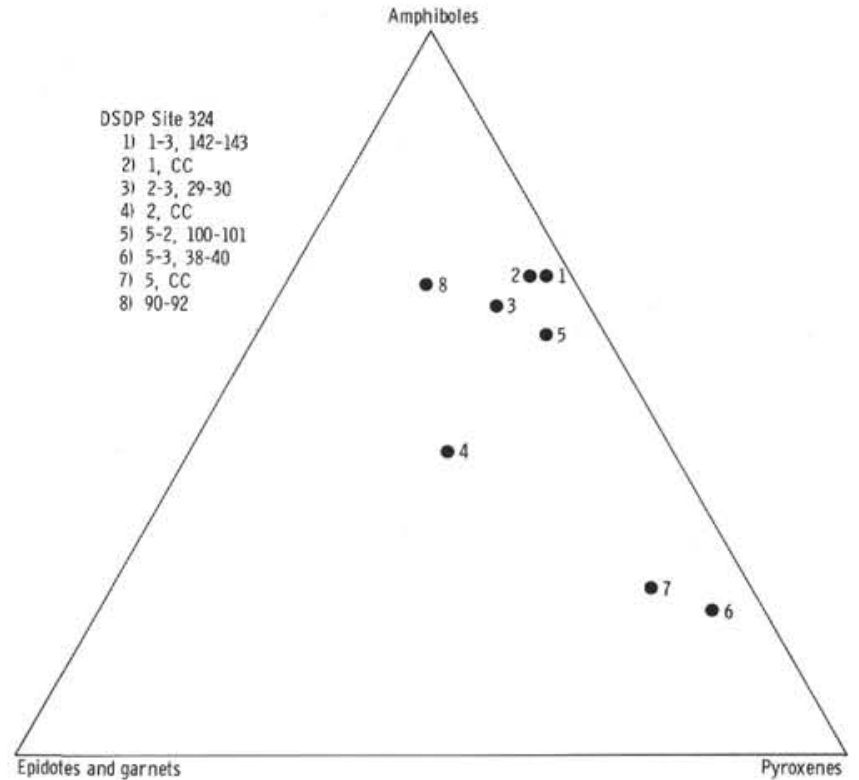

Figure 12. Triangular diagram of heavy mineral suites of Site 324.

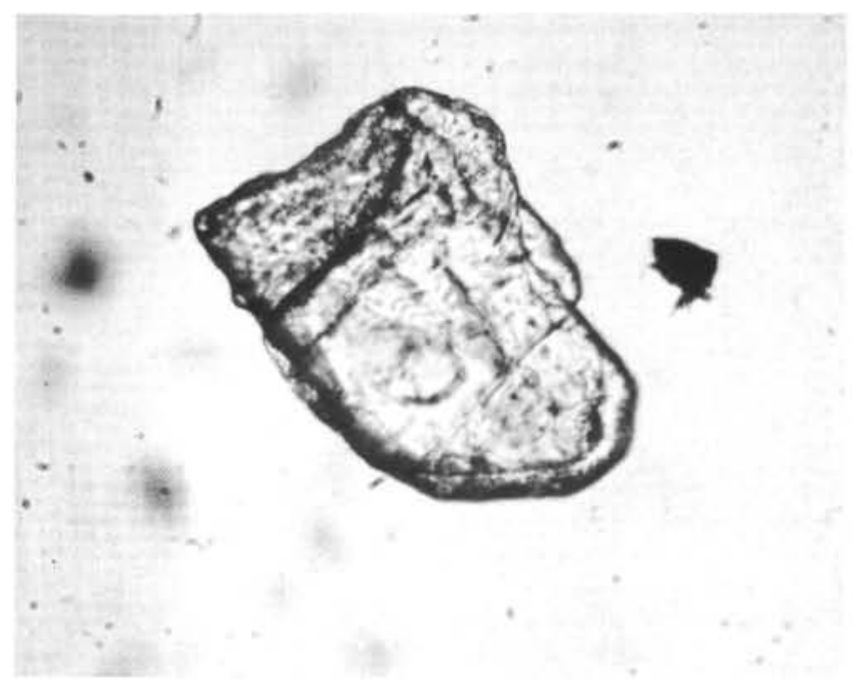

Figure 13. Enstatite, unetched, Sample 324-2-3, 29-30 cm. (See Figure 8 for scale.)

Epidote occurs as a bright yellow, stumpy prismatic grain with a rough surface texture (Figure 23). Zircon is much less common at this than at the other Leg 35 sites.

A triangular etchings diagram shows that the degree of etching successively increases downhole to Core 3 at which point etching becomes markedly more intense (Figure 24). This correlates exactly with the sudden change in mineralogy noted above. The ramifications of this are discussed below.

\section{DISCUSSION}

The following topics will be addressed in our attempt to discuss the processes and provenance of the sediments recovered.

1) geology of the Antarctic continent as it relates to the heavy mineral assemblages of detrital material;

2) seismic profiler data, which defines the structural setting (Tucholke and Houtz, this volume); 


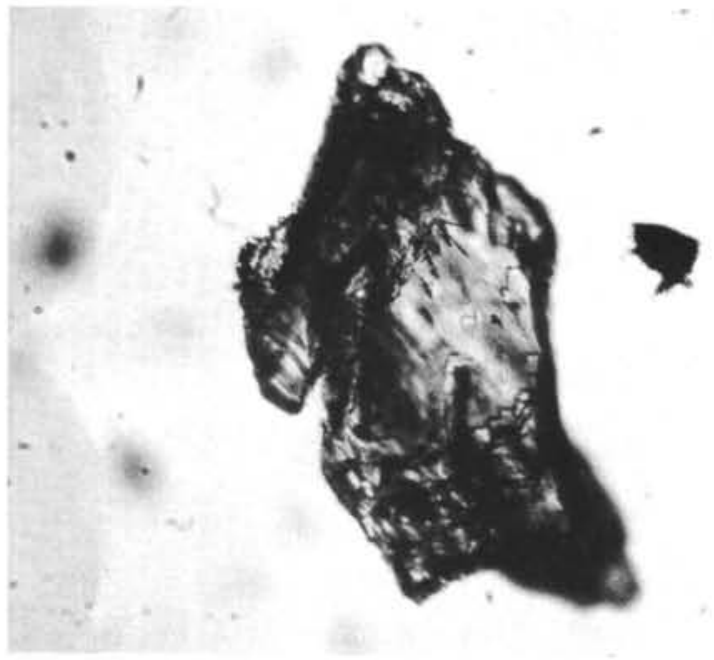

Figure 14. Strongly etched grain of orthopyroxene, Sample 324-2-3, 29-30 cm. (See Figure 8 for scale.)

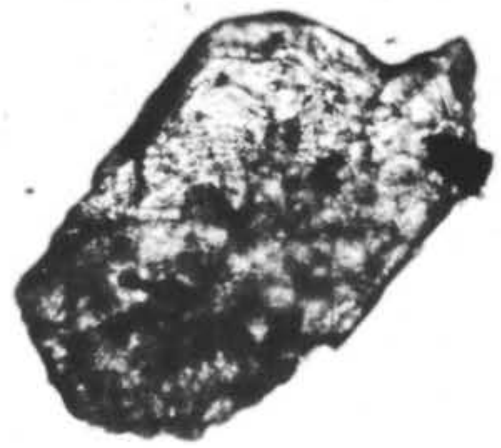

Figure 15. Epidote, showing jagged surface texture, Sample 324-2-3, 24-30 cm. (See Figure 8 for scale.)

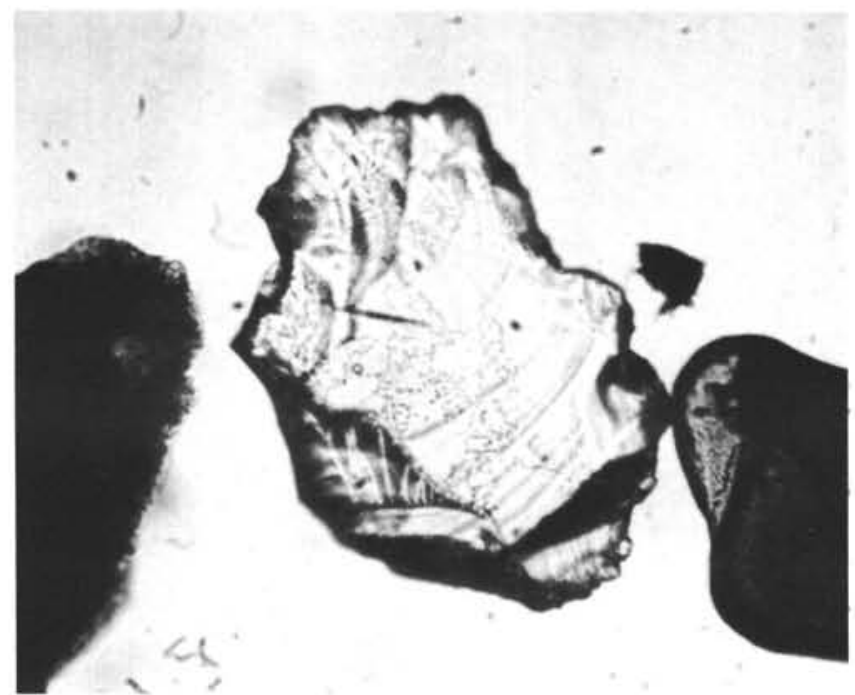

Figure 16. Garnet, showing conchoidal fracture, Sample 324-2-3, 29-30 cm. (See Figure 8 for scale.)

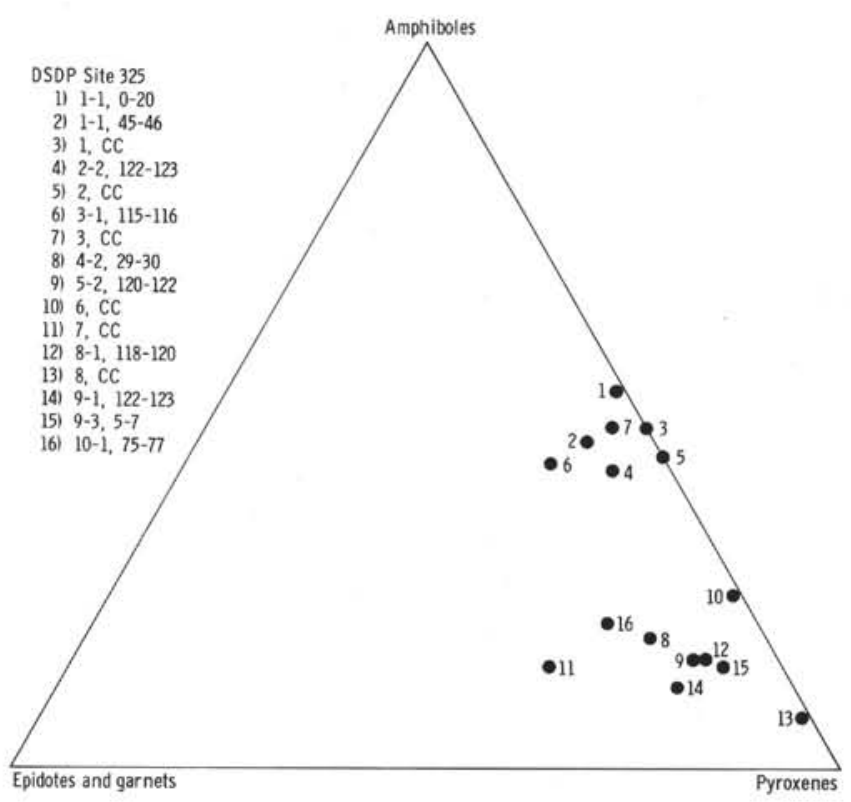

Figure 17. Triangular diagram of heavy mineral suites of Site 325.

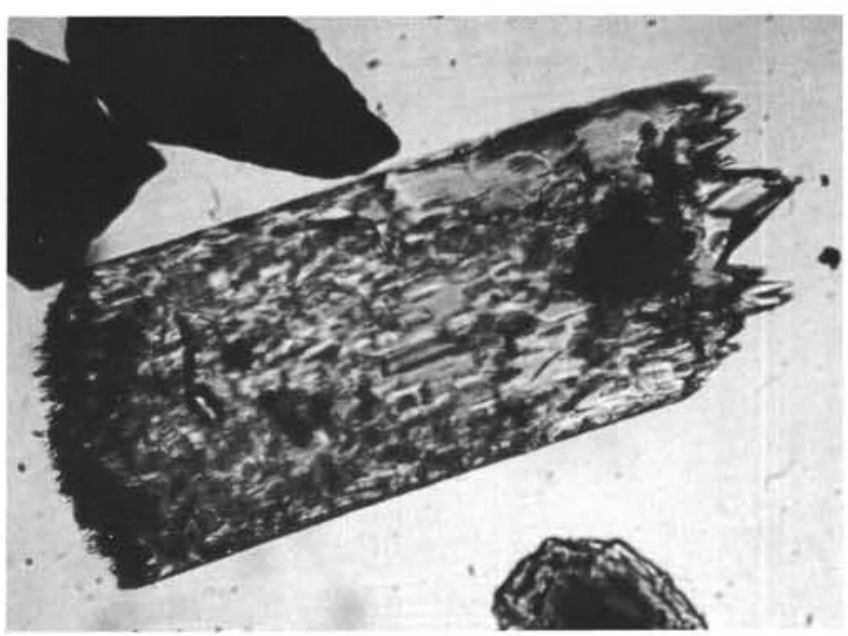

Figure 18. Hypersthene, strongly etched with pitted surface texture, Sample 325-3-1, 115-116 cm. (See Figure 8 for scale.)

3) effect of intrastratal solution on the heavy mineral assemblages with respect to source area, rates of deposition, and depth of burial.

Tucholke and Houtz (this volume) report that topographic and morphologic evidence indicates that the sediment at the four sites was derived from the Antarctic continent and was deposited in a seaward thinning wedge at the base of the continental slope. No evidence exists that basin sediments originate from South America. Because of the similarities between the mineral assemblages and the relative geographic positions at Sites 322 and 325, and Sites 323 and 324, these two groups may be distinguished on the basis of provenance.

The geology of the west coast of Antarctica, from the Antarctic Peninsula to Marie Byrd Land, is dominated by rocks originating from the Andean orogeny (Anderson, 1965). This orogeny yielded intrusives ranging from 


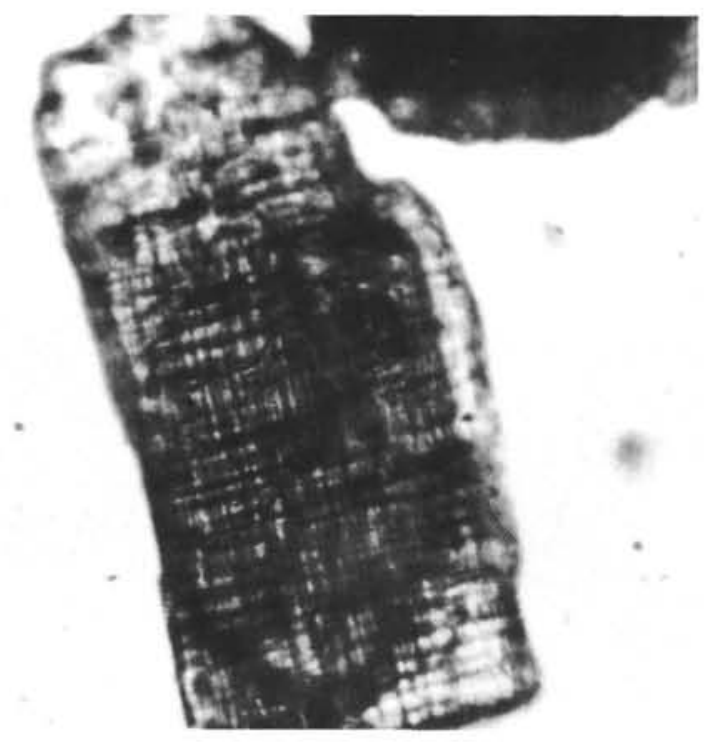

Figure 19. Hypersthene grain showing schiller structure Sample $325-1-1,45-46 \mathrm{~cm}$. (See Figure 8 for scale.)

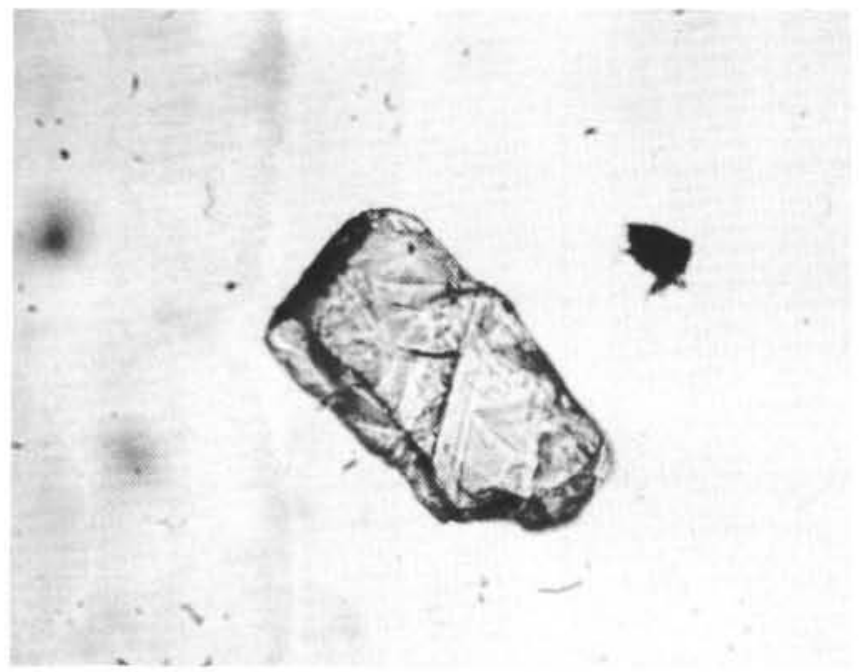

Figure 20. Unetched augite grain, Sample 325-5-2, 120-122 $\mathrm{cm}$. (See Figure 8 for scale.)

granitic to gabbroic composition, with quartz diorite being the most abundant.

The area of the Graham Coast on the Antarctic Peninsula is defined by Upper Cretaceous intrusives overlying Upper Jurassic highly altered pyroclastics and andesites (Curtis, 1966). Modal analyses of olivinegabbros and other gabbros show hornblende and augite to be the dominant mineral species. Hornblende is present as a replacement of augite, as is the case with localized hornblende gabbros, and in some quartz diorites described by Knowles (1945), in the King George VI Sound. This may explain the occurrence of hornblende grains that were similar in appearance to the pyroxenes. The absence of any olivine in the cores is probably because it is a very unstable mineral (Pettijohn, 1949) and consequently is usually found in very recent sediments and beach deposits, and rarely occurs in deep-sea sediments (Milner, 1962).

The earliest intrusives were believed to have been gabbroic, and later intrusions of granodiorite incorporated

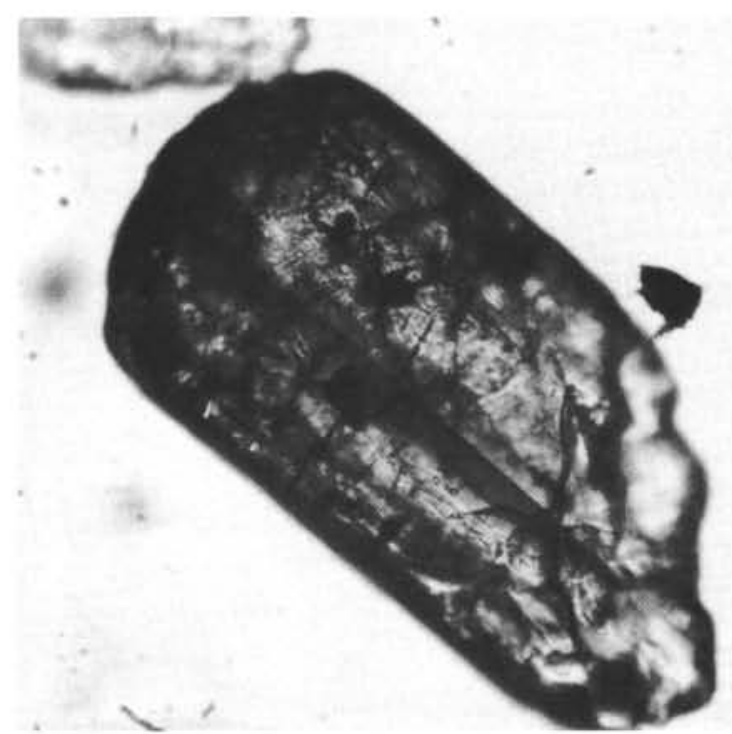

Figure 21. Weakly etched clinopyroxene, Sample 325-1-1, $45-46 \mathrm{~cm}$. (See Figure 8 for scale.)

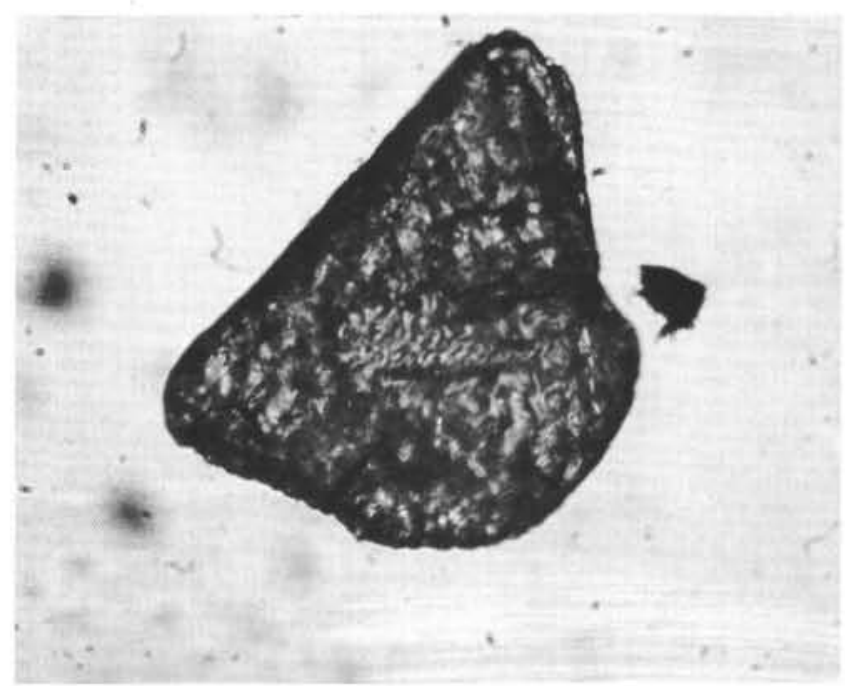

Figure 22. Augite, moderately etched, Sample 325-8-1, $118-120 \mathrm{~cm}$. (See Figure 8 for scale.)

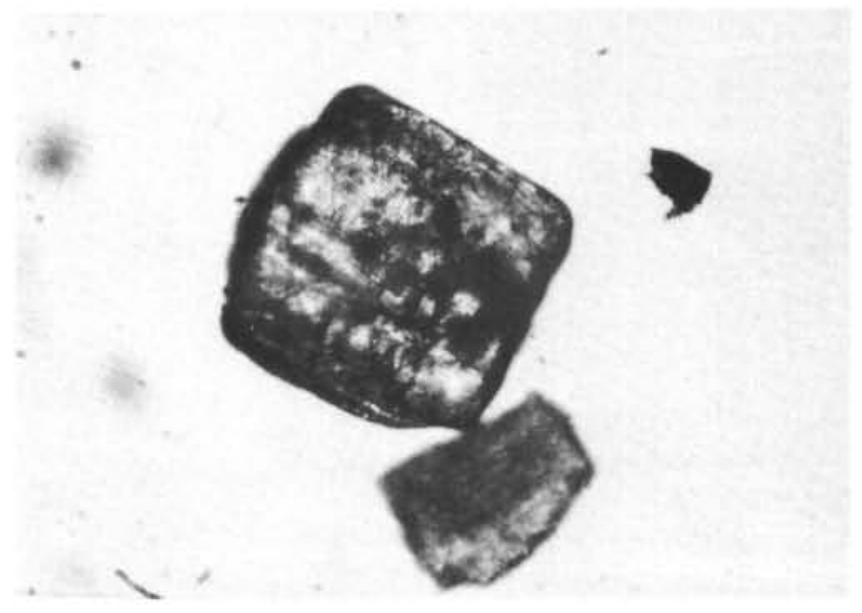

Figure 23. Epidote Sample 325-1-1, 45-46 cm. (See Figure 8 for scale.) 


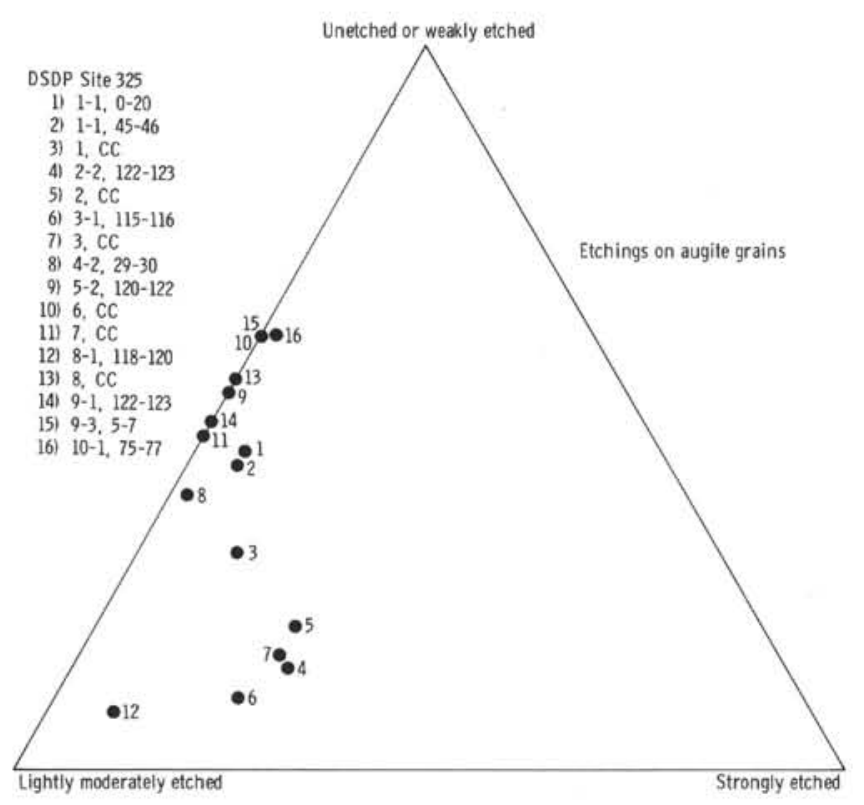

Figure 24. Triangular diagram showing relative degree of etching on clinopyroxene grains at Site 325.

the gabbro into the new magma which resulted in its basification. Successive intrusions of granodiorites became less basic until they reached their present uncontaminated state. For a more detailed description of the geology of the region, see Knowles (1945), Gouldring (1962), and Curtis (1966).

The geology of the Eights Coast region, to which Site 324 is adjacent, is described by Craddock and Hubbard (1961), Drake (1962), Drake et al. (1964). A hornblendebiotite quartz diorite is the dominant rock type which was intruded by basic dikes (Craddock and Hubbard, 1961). Radiometric dates of zircon and biotite (Drake et al., 1964), and rubidium-strontium dates (Craddock et al., 1964a, b) suggest a much older age, at least Middle Jurassic, for these rocks than for those of the Antarctic Peninsula. Localized occurrences of Upper Cretaceous and lower Tertiary volcanics from the Jones Mountains of the Eights Coast Region, which unconformably overlie quartz diorites, are the youngest rocks in the region (Drake, 1962). The Andean orogeny was of less importance in this region; the Eights Coast is characterized by Middle Jurassic and earlier rocks of metamorphic origin, which may have been recrystallized by later plutonics (Drake et al., 1964).

The influence of the geologic terrane of the Eights Coast is reflected in the sediments of Site 324, and possibly Site 323, although at Site 323 recognition of provenance appears to be more complex. Comparatively more amphiboles than pyroxenes were found at Sites 323 and 324 than were found at Sites 322 and 325 reflecting the generally less amount of basic rock. Also the increased amounts of sphene, the micas, and staurolite and kyanite provide additional evidence for the presence of a slightly less basic and somewhat metamorphosed source rock.

van Andel (1959) states that weathering, mechanical destruction during transportation, selective sorting according to size and density, and postdepositional chemical destruction (intrastratal solution) may affect the constituents of the heavy mineral assemblages. The last of these four processes is considered below.

Pettijohn (1949) has shown how intrastratal solution may modify mineral assemblages through time and places great importance on the relative stabilities of mineral species. The findings represented by Figures 5 and 6 appear to agree with those of Pettijohn (1949) and Scheidegger et al. (1973), to the extent that there is a general increase in etched grains downhole at Sites 322 and 325 .

However at Site 325 , at $4-2,29-30 \mathrm{~cm}$, a dramatic decrease in amphiboles relative to pyroxenes occurs which continues downhole. Such a marked change probably cannot be explained by intrastratal solution. If this were the case, etchings on the pyroxene grains should increase and their relative abundance should decrease with time, but in fact, the opposite is true. The number of pyroxene grains increases and they display much less etching than in the younger sediments.

This may indicate that a change in source rock type occurred in the late Miocene or the early Pliocene when ice-rafting became a significant process, and thus may be related to the advent of a period of extensive glaciation as reported by Jacobs (1974), Ciesielski and Weaver (1974), and Kennett and Brunner (1973). The fact that the mineral assemblage changes not only in its content, but also in the degree of intrastratal solution, may also be significant.

Seismic profiler data (Tucholke and Houtz, this volume) indicate a possible massive sheet-like flow of coarse clastic sediments in the early Pliocene and relate this to the advance of a glacier (Ciesielski and Weaver, 1974). The reflecting horizon suggested this flow is common to both Sites 324 and 325 , but it is difficult to assess the influence of glaciation on Site 324. Tucholke and Houtz (this volume) note this in regards to the effect of ice-rafting on the acoustic character of the sediment of the rise. Also, since Site 324 penetrated only to sediments of late Miocene age, the lower portion of the sequence comparison with contemporaneous sediments at Site 325 is not available.

The age of the sediment from Site 322 postdates the early Miocene age suggested by Tucholke and Houtz (this volume) as the time when terrigenous material finally reached that site. Its mineralogic composition is more similar to the older assemblage found at Site 325 than the younger one. The mineralogy of Site 322 remains fairly consistent throughout the hole which suggests that it has not been affected by the supposed change in source rock type that Site 325 has undergone. Because Site 322 is further offshore than Site 325 , it may not have been influenced by the glaciation as greatly as Site 325 , if indeed the glaciation was related to the change in source rock type of that site. The degree of intrastratal solution increases downhole which may be related to the effect of increased water content in sediments deposited at relatively high rates.

Rock type patterns of the Antarctic Peninsula show that the early intrusions were of an increasingly gabbroic nature, and since the heavy minerals from Site 325 reflect this, it is possible that glaciation may have suddenly brought upon a mineralogic change by eroding 
into younger, less basic intrusives of granodioritic composition. In this way the glaciation may be related to changes in source rock type. The evidence to suggest such a conclusion, however, is not extremely strong.

As noted earlier, no discernible patterns can be detected at Sites 323 and 324. However, preliminary investigation seems to indicate a common source area, i.e., the area of the Eights Coast, and volcanics from the Jones Mountains and Peter I Island.

\section{CONCLUSIONS}

Modal analysis and etching patterns of heavy minerals from the Bellingshausen basin and the Antarctic continental rise revealed that:

1) The source rock for sediments found at all four sites is from the western Antarctic region. Sites 322 and 325 are believed to have received sediments from the same general source, comprising Upper Cretaceous or possibly younger intrusives of the Antarctic Peninsula. Sites 323 and 324 ultimately derived their sediment from older Middle Jurassic intrusives and metamorphics which were later intruded by mafics, from the Eights Coast region.

2) A change in source rock type reflected at Site 325 , where a dominant pyroxene-amphibole gives way to a pyroxene assemblage downhole. This change was not noted at Site 322 and we believe that it is related to the advent of a late Miocene or early Pliocene glaciation resulting in erosion of greater amounts of the younger, less basic intrusives.

3) Further evidence of glaciation affecting the mineral suites at Site 325 is suggested by the increasing (downhole) degree of etching on clinopyroxene which may be related to greater interstitial circulation in rapidly deposited, watery, glacial marine sediment.

\section{REFERENCES}

Anderson, J.J., 1965. Bedrock geology of Antarctica: a summary of exploration 1831-1962. In Hadley, J.B. (Ed.), Geology and paleontology of the Antarctic; Antarctic Res. Ser.: Washington (American Geophys. Union), v. 6, p. 170.

Blatt, H. and Sutherland, B., 1969. Intrastratal solution and non-opaque heavy minerals in shales: J. Sediment. Petrol., v. 39 , p. $591-600$.

Craddock, C. and Hubbard, H.P., 1961. Preliminary geologic report on the 1960 U.S. expedition to Bellingshausen Sea, Antarctica: Science, v. 133, p. 886-887.
Craddock, C., Bastien. T.W., and Rutford, R., 1964. Geology of the Jones Mt. area. In Adie, R.J. (Ed.), Antarctic geology, Proc. 1st Internat. Symp. Antarctic Geology, Capetown 16-21 Sept. 1963: Amsterdam, (North-Holland), p. 171-187.

Craddock, C., Gast, P.W., Hanson, G.N., and Linden, H., 1964b. Rubdium-strontium ages from Antarctica: Geol. Soc. Am. Bull., v. 75, p. 237-240.

Ciesielski, P.F. and Weaver, F.M., 1974. Early Pliocene temperature changes in the Antarctic Seas: Geology, v. 2, p. $511-515$.

Curtis, R., 1966. The petrology of the Graham Coast, Graham Land: Sci. Rep. 50, British Antarctic Surv.

Drake, A.A., 1962. Preliminary geologic report on the 1961 U.S. expedition to Bellingshausen Sea, Antarctica: Science, v. 135 , p. $671-672$.

Drake, A.A., Stern, T.W., and Thomas, H.H., 1964. Radiometric ages of zircon and biotite in quartz diorite, Eights Coast, Antarctica: U.S. Geol. Surv. Prof. Paper 500D, p. 503.

Gouldring, D.C., 1962. The geology of the Loubet Coast, Graham Land: Sci. Rept. 36, British Antarctic Surv.

Hollister, C.D. and Heezen, B.C., 1967. The floor of the Bellingshausen Sea: Deep-Sea Photogr., Johns Hopkins Oceanogr. Stud., no. 3, p. 177-189.

Jacobs, M.B., 1974. Clay mineral changes in Antarctic deepsea sediments and Cenozoic climatic events: J. Sediment. Petrol., v. 14, p. 1079-1086.

Kennett, J.P. and Brunner, C.A., 1973. Antarctic late Cenozoic glaciation: Evidence for initiation of ice rafting and inferred increased bottom water activity: Geol. Soc. Am. Bull., v. 84, p. 2043-2052.

Knowles, P.H., 1945. Geology of southern Palmer Peninsula, Antarctica: Proc. Am. Phil. Soc., v. 89, p. 132-145.

McKnight, B.K., 1974. Heavy mineral content of sediments from Deep Sea Drill Sites 259-263, Eastern Indian Ocean. In Veevers, J.J., Heirtzler, J.R., et al., Initial Reports of the Deep Sea Drilling Project, Volume 27: Washington (U.S. Government Printing Office), p. 523-534.

Milner, H.B., 1962. Sedimentary Petrography, Vol II: New York (Macmillan).

Pettijohn, F.J., 1941. Persistence of heavy minerals and geologic age: J. Geol., v. 49, p. 610-625.

, 1949. Sedimentary rocks: New York (Harpert Brothers).

Scheiddegger, K.F., Kulm, L.D., and Piper, D.J.W., 1973. Heavy mineralogy of unconsolidated sands in northeastern Pacific sediments: Leg 18, Deep Sea Drilling Project. In Kulm, L.D., von Huene, R., et al., Initial Reports of the Deep Sea Drilling Project, Volume 18: Washington (U.S. Government Printing Office), p. 877-884.

van Andel, Tj.H., 1959. Reflections on the interpretation of heavy mineral analyses: J. Sediment. Petrol., v. 29, p. 153163. 